\title{
STRATEGI KOMERSIALISASI INVENSI PERGURUAN TINGGI
}

\author{
Mokhamad Syaefudin Andrianto \\ Departemen Manajemen, Fakultas Ekonomi dan Manajemen (FEM) \\ Institut Pertanian Bogor (IPB), Bogor 16680 \\ *Email: syaefudin1@apps.ipb.ac.id/syaefudinandri@gmail.com
}

\begin{abstract}
RINGKASAN
Tingkat komersialisasi invensi perguruan tinggi memiliki persentase yang masih rendah. Umumnya inventor perguruan tinggi merasa kesulitan karena beberapa keterbatasan seperti akses pasar, finansial, SDM, pengetahuan dan keterampilan. Oleh karena itu, Tujuan dari kajian ini adalah mengembangkan analisis rekayasa manajerial agar komersialisasi dapat meningkat. Rekayasa manajerial dapat dikelompokkan kedalam level makro, meso dan mikro. Level makro terkait dengan kebijakan nasional, level meso terkait dengan lembaga penghubung dan level mikro terkait dengan unit invensi. Strategi makro terkait regulasi dan insentif. Level meso menjadi pendorong komersialisasi secara strategis dengan melakukan pemetaan kebutuhan, riset pasar, sinergi dan sinkronisasi start up capital, menghubungkan dengan pihak ketiga melalui bursa invensi, pameran invensi dan temu bisnis. Level mikro terkait dengan pengembangan strategi komersialisasi tiap klaster/unit yang khas. Strategi komersialisasi dapat dikelompokkan kedalam pengembangan usaha baru (university spin off), joint/ aliansi, lisensi dan jual putus. Pengembangan komersialisasi melalui university spin off lebih memungkinkan bila disertai riset pasar dan model bisnis yang baik untuk menjembatani konsep product driven beralih ke market driven.
\end{abstract}

Kata kunci: invensi, inovasi, rekayasa manajerial, riset pasar, university spin off

\section{PERNYATAAN KUNCI}

- Inovasi adalah salah satu kunci utama dalam meningkatkan daya saing nasional. Inovasi dapat berasal dari invensi perguruan tinggi yang diadopsi oleh masyarakat. Jumlah diseminasi invensi merupakan salah satu ukuran kontribusi perguruan tinggi kepada masyarakat. Invensi ini ada yang dapat dikembangkan untuk kepentingan sosial maupun komersial.
- Jumlah invensi perguruan tinggi yang dimanfaatkan masyarakat ataupun perusahaan masih terbatas. Keterbatasan ini antara lain disebabkan oleh faktor manajemen. Disisi lain pendekatan product driven membutuhkan edukasi pasar yang ekstra dibanding pendekatan market driven.

- Rekayasa manajerial dapat digunakan untuk meningkatkan komersialisasi invensi pada level makro, meso dan mikro. 


\section{REKOMENDASI KEBIJAKAN}

- Konsep kebijakan dibagi kedalam 3 level yaitu level makro, meso dan mikro. Level makro terkait dengan regulasi dan insentif inovasi. Level meso terkait dengan pengembangan Transfer/Liaison Technology Office (selanjutnya disebutTTO/LTO) dan level mikro terkait dengan strategi komersialisi klaster atau unit invensi tertentu.

- Pada level makro diperlukan regulasi, roadmap dan konsep yang mendukung inovasi seperti pengembangan konsep technopolis (kota berbasis technology). Sebagai contoh, IPB dengan karakter pertanian dapat bekerjasama dengan pelaku usaha, pemerintah pusat dan daerah, serta komunitas dalam mengembangkan technopolis berbasis pertanian atau disebut agropolitan. Etalase evolusi berbagai konsep dan teknologi pertanian dari paling sederhana hingga paling mutakhir dapat disajikan melalui ecotourist. Sukses agropolitan dapat mengangkat citra pertanian sehingga pemuda dan mahasiswa lebih tertarik berprofesi di bidang pertanian secara luas.

- Pada level meso perlu pengembangan TTO/LTO yang mengelola invensi secara profesional misalkan dengan mengadakan kegiatan bursa invensi dan kompetisi, valuasi teknologi, dan mendorong university spin off. Bursa invensi secara berkala dapat dijadikan sarana untuk mendiseminasi invensi dan mendalami keinginan pasar. Kompetisi dimanfaatkan untuk meningkatkan motivasi menemukan invensi, sedangkan valuasi invensi digunakan untuk memprioritaskan bantuan pengembangan. Komersialisasi yang rendah dan kurangnya minat pebisnis dapat dijadikan alternatif alasan untuk mengembangkan university spin off. Konsep entrepreneurial university dapat diterapkan dengan memanfaatkan dan memasarkan invensi.

- Pada level mikro perlu pengembangan strategi komersialisasi. Inventor perguruan tinggi umumnya enggan atau merasa berat bila harus mengembangkan inovasi hingga ke pasar karena berbagai keterbatasan. Lembaga perantara (TTO/LTO) dapat melakukan pengelompokan/klasterisasi invensi sesuai dengan karakteristik produk dan pasar serta mengembangkan strategi. Strategi komersialisasi tiap klaster dapat berbeda sesuai dengan karakteristik produk. Terdapat 4 strategi korporat, yaitu: mengembangkan sendiri, joint/aliansi, lisensi dan jual putus. Untuk mengurangi resiko harus disusun model bisnis sebagai acuan dalam pengembangan invensi. Hal ini dapat dilakukan sinergi dengan mahasiswa fakultas ekonomi dan manajemen/bisnis melalui proyek mini dan riset.

\section{PENDAHULUAN}

Diseminasi invensi perguruan tinggi melalui komersialisasi mendapatkan tantangan pro-kontra terutama dari sisi tugas dan fungsi perguruan tinggi. Di sisi lain berkembangnya konsep Entrepreneurial University mendorong semangat kewirausahaan dimana perguruan tinggi tidak hanya menciptakan pekerja tetapi juga pengusaha yang dibutuhkan oleh bangsa. Diseminasi atau difusi teknologi melalui komersialisasi diatur dengan UU No 12 tahun 2002 dimana perguruan tinggi atau lembaga penelitian dan pengembangan ditugaskan untuk melakukan difusi teknologi termasuk mencari mitra dan jaringan melalui 


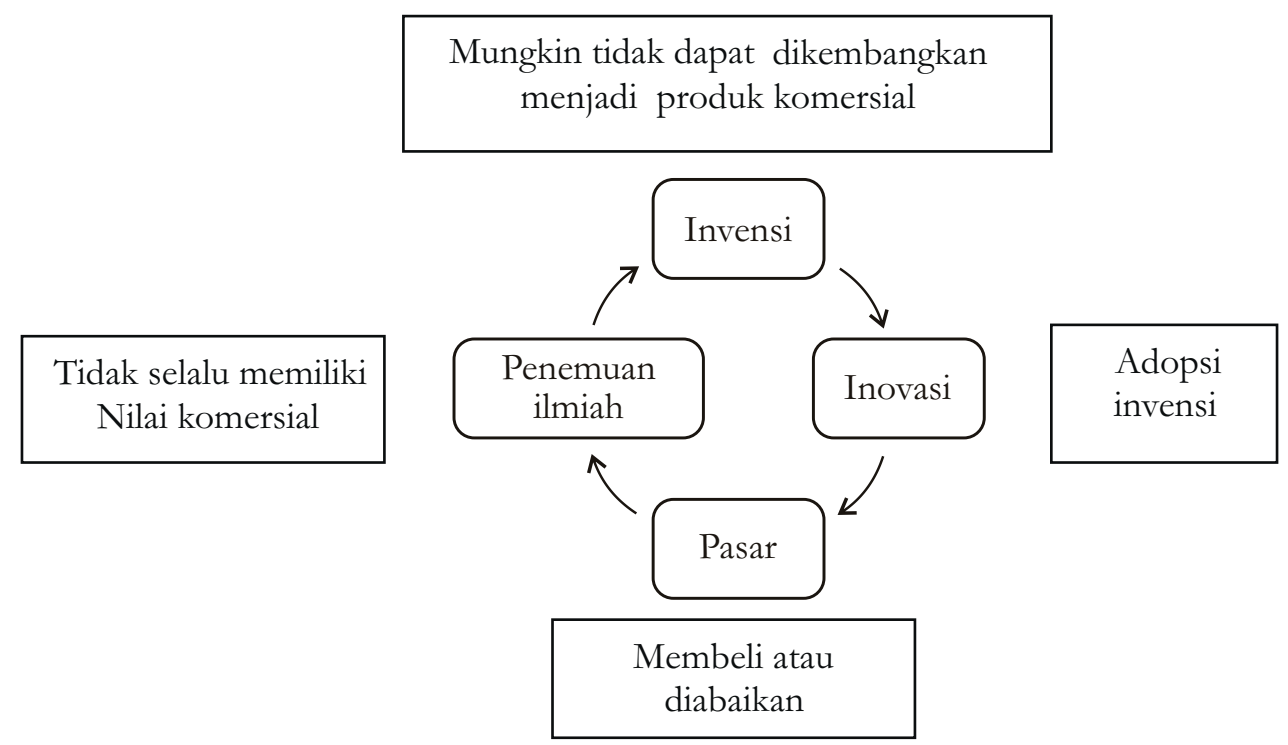

Gambar 1. Komponen Siklus Inovasi (Khalil, 2000)

badan usaha. Hal ini menjadi peluang untuk perguruan tinggi yang memiliki invensi cukup banyak tetapi kesulitan dalam melakukan diseminasi atau tingkat adopsi invensi masih rendah.

Sebagian temuan ilmiah dapat memiliki nilai komersial. Produk akhir temuan ilmiah dapat berupa jurnal, buku atau invensi. Invensi yang biasanya memiliki nilai komersial, didefinisikan sebagai ide inventor yang dituangkan ke dalam suatu kegiatan pemecahan masalah yang spesifik di bidang teknologi dapat berupa produk atau proses atau penyempurnaan dan pengembangan produk atau proses. Produk invensi dapat berupa barang, jasa (ide, proses, teknologi) atau keduanya yang pada tingkatan tertentu dapat diajukan paten (Ditjen Haki RI, 2005; Dit. RKS IPB, 2011). Invensi-invensi tertentu memiliki potensi ditingkatkan menjadi produk komersial yang diterima pasar. Invensi, agar diserap pasar, membutuhkan inovasi. Inovasi adalah kreativitas yang diwujudkan dalam bentuk produk atau jasa. Bentuk produk atau jasa ini relatif lebih mudah dinilai, dievaluasi atau dimodifikasi sehingga dapat dipasarkan. Produk inovasi yang sudah dipasarkan dapat dievaluasi apakah diterima pasar atau tidak. Evaluasi ini dapat menjadi penemuan ilmiah untuk dikembangkan produk berikutnya. Siklus ini oleh Khalil (2000) disebut sebagai komponen siklus inovasi (Gambar 1).

Keterbatasan inventor umumnya beragam mulai dari mengakses pasar, skala ekonomis produksi, sumber daya manusia hingga kebutuhan modal untuk mengembangkan. Umumnya produk invensi adalah product driven sehingga membutuhkan inovasi agar diterima pasar. Oleh karena itu diperlukan rekayasa manajerial pada level makro, meso dan mikro.

\section{SITUASI TERKINI}

Undang-undang No. 18 Tahun 2002 tentang Sistem Nasional Penelitian, Pengembangan, dan Penerapan Ilmu Pengetahuan dan Teknologi menjadi payung hukum untuk pengembangan komersialisasi invensi. Pemerintah daerah juga diperkuat dengan Peraturan bersama 
Permenristek no 3 tahun 2012 dan Permendagri no 36 tahun 2012 tekait sistem inovasi daerah (SiDa). Alih teknologi bagi perguruan tinggi bersifat wajib sesuai dengan Peraturan Pemerintah (PP) No 20 tahun 2005, pasal 2, yang menyebutkan "Perguruan tinggi dan lembaga litbang wajib mengusahakan alih teknologi kekayaan intelektual serta hasil kegiatan penelitian dan pengembangan yang dihasilkan melalui kegiatan penelitian dan pengembangan yang dibiayai sepenuhnya atau sebagian oleh pemerintah dan/atau pemerintah daerah sejauh tidak bertentangan dengan ketertiban umum dan peraturan perundang-undangan" (KNRT 2006).

Alih teknologi oleh universitas dapat dilakukan dengan beberapa cara. Alih teknologi didalam mendorong peningkatan perekonomian dan daya saing nasional menurut Allen dan Norling (1991), dapat dilakukan melalui: (1) penyediaan sumber daya manusia yang terlatih dan termotivasi, (2) penelitian yang dikembangkan selaras dengan kebutuhan industri, (3) asistensi teknis dan manajerial terhadap pengembangan kesejahteraan komunitas/ kelompok masyarakat, pemanfaataan fasilitas dan teknologi canggih yang dimiliki oleh universitas sebagai referensi oleh perusahaan atau masyarakat, dan (5) mengembangkan lingkungan yang mendukung komersialisasi. Pendekatan terakhir mengandung kontroversi tetapi akhir-akhir ini beberapa aktivitas komersial telah dipandang positif.

Pada level nasional, selain dibentuk lembaga yang mempercepat inovasi nasional seperti Dewan Riset Nasional, beberapa pihak memfasilitasi invensi dengan kompetisi seperti yang dilakukan oleh Bussiness Innovation Centre (BIC). Kompetisi BIC dilakukan tiap tahun sejak tahun 2008 dengan menyajikan 100 inovasi Indonesia paling prospektif dan tiap tahun ditambahkan satu sehingga menjadi 101, 102, 103,104,105,106 dan kini tahun 2016, 107 inovasi paling prospektif. IPB mencatatkan 278 dari 721 inovasi Indonesia pada kompetisi yang diselenggarakan BIC (DRI, 2014). Selain hal tersebut, pada tahun 2017, Kemenristekdikti juga merencanakan pengembangan 12 Science Techno Park (STP). Lingkungan yang mendukung inovasi sangat penting. Konsep technopolis menjadi alternatif penting dalam mendorong inovasi seperti yang dilakukan di USA (Silicon Valley, Austin, Phoenix, Gibson dan Smilor, 1991), Malaysia (Malaysia Multimedia Super Corridor), di Italia Selatan TCNO (Technopolis Novus Ortus). Technopolis adalah kota berbasis teknologi atau komunitas yang mendukung technology driven.

Perguruan Tinggi umumnya menempatkan diseminasi invensi dalam pengelolaan lembaga penelitian. Beberapa perguruan tinggi memberikan perhatian khusus seperti IPB di bawah pengelolaan Direktorat Riset dan Inovasi (DRI IPB), UI dikelola oleh Direktorat Inovasi dan Inkubator Bisnis Universitas Indonesia (DIIB UI), UNAIR dikelola oleh Lembaga Penelitian dan Inovasi (LPI) UNAIR, ITB dikelola oleh Lembaga Pengembangan Inovasi Kewirausahaan (LPIK) ITB. Pengelola membantu mencari mitra yang sesuai baik pengusaha/industri, calon pembeli teknologi, calon wirausaha, investor, dan pemerintah. Selain itu, pengelola dapat membuat alternatif-alternatif strategi komersialisasi yang efektif sesuai dengan karakteristik produk. Dalam hal pengelolaan invensi, IPB lebih maju dengan Direktorat Riset dan Inovasi dan pengembangan bisnis PT BLST yang memiliki 3 lini bisnis yaitu science based, service based dan asset based. Serambi botani merupakan outlet sebagai wadah komersialisasi invensi khususnya pangan. 
Penelitian terkait strategi komersialisasi invensi masih terbatas. Penelitian terkait strategi komersialisasi invensi antara lain manajemen strategi pengelolaan invensi (Andrianto et al., 2011; Nugrahani, 2011), strategi pemasaran (Rizki et al., 2013) dan valuasi teknologi (Dharmawan, 2007; Febriani, 2014).

\section{ANALISIS DAN ALTERNATIF SOLUSI}

Pendekatan metode kebijakan dilakukan menggunakan analisis makro, meso dan mikro (Jeurissen, 1997; Banjade et al., 2007; Shanahan et al., 2011). Pada konteks analisis makro terkait institusi pembuat kebijakan dan lingkungan yang kondusif, pada konteks analisis meso terkait dengan sinergi kelompok dan penciptaan budaya yang inovatif, dan pada konteks mikro terkait dengan keterlibatan individu dalam kebijakan yang lebih progresif.

Pada level makro alternatif solusi melibatkan kebijakan nasional terutama dari Kemenristekdikti. Direktorat Jenderal Penguatan Inovasi mendorong kemitraan peneliti dan pihak swasta dan BUMN.

Pada level meso, rekayasa manajerial penting dalam mendorong semangat menghasilkan invensi yang lebih banyak. Lembaga TTO penting terutama terkait dengan pengelolaan Hak Atas Kekayaan Intelektual (HaKI). Strategi komersialisasi tiap TTO dapat beragam. Misalkan untuk strategi komersialisasi produk invensi makanan-minuman IPB menurut Andrianto (2011) dapat dilakukan melalui: (1) pemetaan kebutuhan, tahapan dan prioritas invensi melalui klasterisasi, (2) riset pasar dan tren kebutuhan konsumen terutama terkait pengembangan produk berbasis sumber daya lokal, diversifikasi pangan yang sesuai dengan pasar (konsumen), (3) revitalisasi aktivitas inkubasi invensi sampai layak skala komersial dan sinkronisasi program pendanaan wirausaha dengan start up capital, (4) aliansi /joint development (produksi, pemasaran, SDM, finansial), dan (5) revitalisasi area/bursa produk invensi. Dharmawan (2007) menyarankan valuasi teknologi berorientasi paten sehingga dapat dievaluasi kelayakan ataupun prioritasnya.

Pada tingkat mikro strategi unit invensi dikelompokkan dalam 4 kategori, yaitu: (1) menciptakan usaha baru (create new venture), (2) pemberian lisensi atau royalti, (3) penjualan paten, dan (4) joint venture (Dharmawan, 2007; Dit. RKS IPB, 2011; Andrianto, 2011). Masing-masing bentuk memiliki keunggulan dan kelemahan. Kontrol inventor terhadap sumberdaya usaha menentukan bentuk komersialisasi. Kontrol sumber daya inventor semakin turun dari bentuk usaha baru, join, lisensi dan jual putus. TTO memiliki peran yang strategis dalam membantu memilihkan strategi berdasarkan karakteristik produk dan pasar serta membantu meningkatkan komersialisasi.

Produk invensi umumnya technology driven bukan market driven. Menurut Crawford dan Benedetto (2008) produk invensi yang dikendalikan oleh teknologi (technology drivers) memiliki kekuatan laboratorium sedangkan produk invensi yang dikendalikan oleh pasar (market drivers) memiliki kekuatan berdasarkan pada permasalahan konsumen. Pendekatan lainnya adalah kombinasi dari keduanya.

Daftar invensi dapat diidentifikasi, dikelompokkan (klasterisasi), dievaluasi dan ditentukan pengembangannya. Selain pertimbangan evaluator, ada beberapa inventor yang tidak berkenan dikembangkan secara 
komersial tetapi dapat dimanfaatkan masyarakat secara luas sehingga dapat dikembangkan dengan diseminasi dan skema bantuan sosial. Invensi yang potensial dikembangkan secara komersial dapat dipromosikan misalkan pada bursa invensi, selain itu juga dapat didorong pembentukan tim pengembang atau mitra, kemudian disusun kelayakan bisnis termasuk risiko dan skema bagi hasil. Bila hal ini cukup menarik bisa ditawarkan ke sumber dana atau start up capital. Sumber start up capital ini cukup beragam baik dari pemerintah, Lembaga Non profit atau yayasan, lembaga komersial seperti bank dan dari pengusaha. Tim atau mitra/pengusaha melakukan tes pasar dan launching produk. Dalam jangka waktu dikaji secara keberlanjutan terutama dari hasil riset pasar agar dapat berkembang. Hasil riset pasar dapat dijadikan masukan untuk inventor dan pengembangan produk baru. Level meso memiliki peran yang strategis dalam mendorong komersialisasi invensi. Skema ini dapat dilihat pada Gambar 2.
Contoh kajian kebijakan tingkat meso yang dilakukan oleh Andrianto (2011) dianggap masih relevan. Pemetaan posisi dilakukan pada tahapan invensi, preferensi bentuk komersialisasi dan perkiraan modal yang dibutuhkan. Pemetaan posisi diperlukan terkait dengan persiapan komersialisasi dan sinergi yang dibutuhkan investor, semakin awal posisi semakin besar resiko investor. Harapan komersialisasi inventor atau timnya terkait dengan pilihan komersialisasi yaitu mengembangkan sendiri (spin off), join, lisensi dan jual putus, sedangkan modal yang dibutuhkan terkait dengan perkiraan awal bila ada investor yang berminat dengan modal tertentu. Penelitian dengan sampel 32 invensi pada kasus invensi makanan-minuman IPB dari daftar invensi (Dit.RKS, 2010) hasilnya disajikan dalam uraian berikut:

\section{Posisi tahapan invensi}

Tahapan komersialisasi dibagi kedalam inisiasi, skala labororatorium atau uji lapang, pilot project,

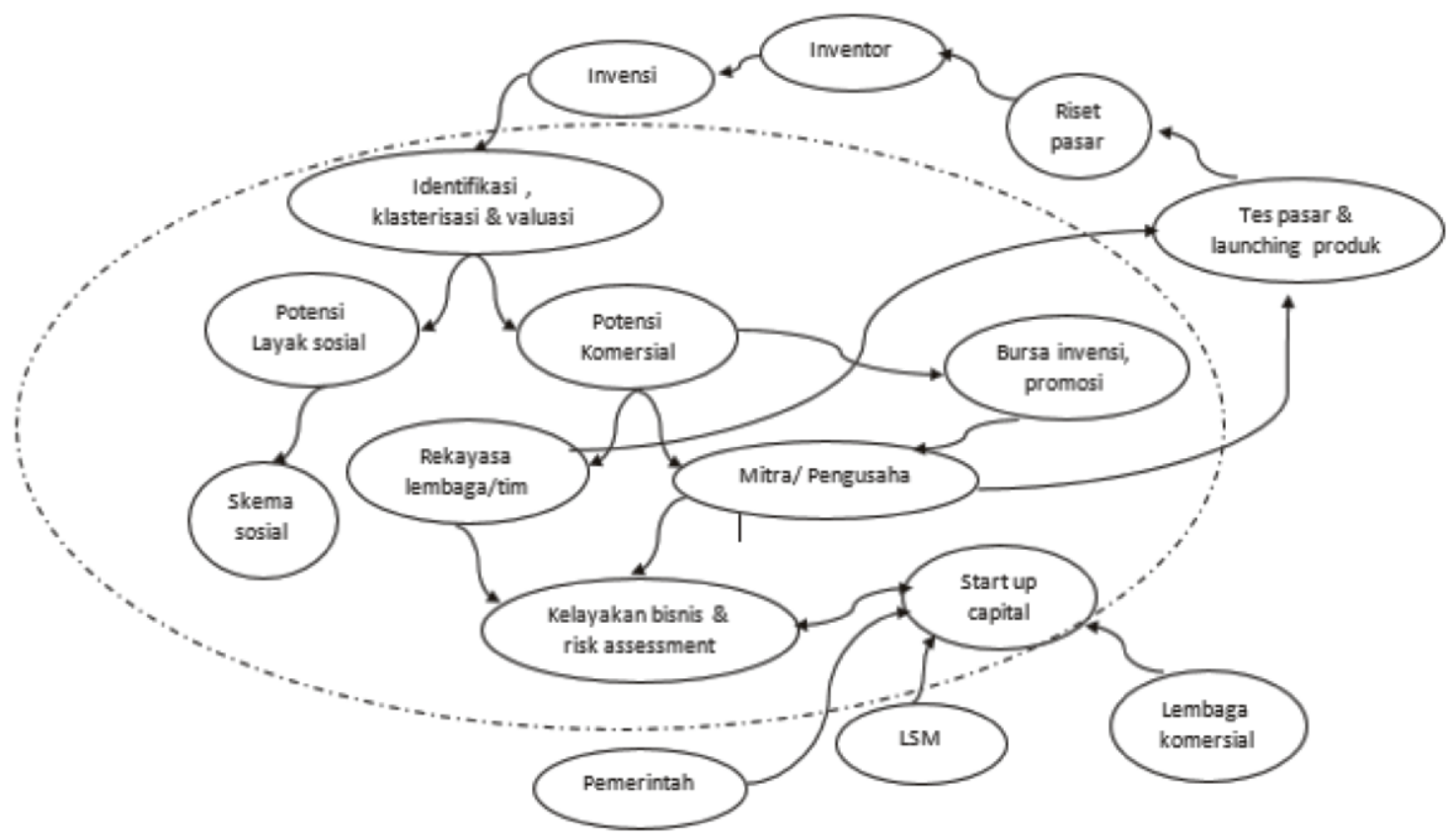

Ket: --------Level meso

Gambar 2 Rekayasa strategi komersialisasi yang efektif 
siap pakai, semi komersial dan komersial. Pada tahap inisiasi atau masih dalam penelitian, ide ini sudah dikompetisikan dan dinyatakan prospektif untuk dikomersialkan dan sudah ada prototype. Tahap berikutnya diuji di laboratorium atau di lapangan lebih lanjut terkait dengan penerimaan tahap awal konsumen, misalkan pada pangan sudah melakukan uji organoleptik. Tahapan pilot projectsudah didanai oleh pihak lain untuk tes pasar dan biasanya sudah memiliki studi kelayakan bisnis. Tahapan siap pakai terkait dengan kesiapan atau kondisi pasar. Produk sudah siap dikomersialkan tetapi karena beberapa keterbatasan belum dikomersialkan, misalkan ketersediaan bahan baku, operasional bisnis, kontinuitas, skala ekonomis dan keterbatasan lainnya.

Tahapan selanjutnya adalah semi komersial dan komersial. Pada tahapan semi komersial dan komersial produk sudah dikemas dan dijual seperti biasa misalkan melalu outlet serambi botani. Pada skala semi komersial produk diproduksi bila ada pesanan misalkan untuk pameran, oleh-oleh dan sebagainya. Pada skala komersial sudah diproduksi reguler. Mayoritas invensi berada pada tahapan skala laboratorium dan siap pakai (Gambar 3). Sebagian kecil sudah dikomersialkan atau diproduksi ketika ada pesanan. Tahapan ini menjadi salah satu pertimbangan industri/pengusaha karena kecenderungan investor/pengusaha menginginkan invensi yang sudah berjalan atau berproduksi.

\section{Preferensi bentuk komersialisasi}

Bentuk komersialisasi dipengaruhi oleh harapan inventor dan timnya antara lain menciptakan usaha, mengembangkan usaha baru, mengakuisisi perusahaan oleh inventor atau tim dan dapat disebut university spin-off. Anggota fakultas baik dosen, staf ataupun mahasiswa yang terlibat penelitian akan menjalankan usaha dan mungkin meninggalkan universitas entrepreneur. Contoh perusahaan spin-off adalah HewlettPackard dari Stanford University dan Digital Equipment Corporation dari MIT (Brett et al., 1991), sedangkan di IPB contohnya adalah boneka horta yang merupakan produk PKM mahasiswa

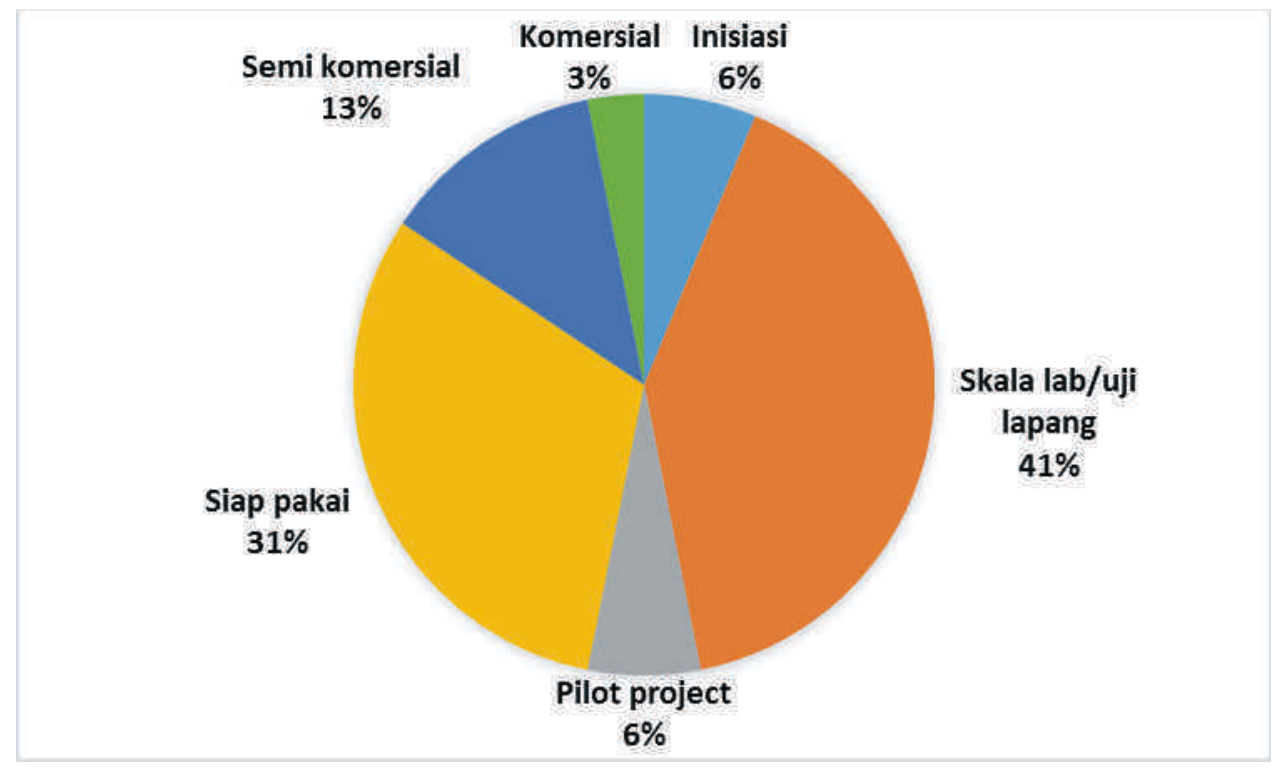

Gambar 3 Tahapan kesiapan invensi (Andrianto, 2011) 
yang dikembangkan secara serius sebagai invensi alat edukasi pertanian. Komersialisasi riset melalui spin off masih sangat kecil oleh karena di USA dikembangkan TTN (Transfer Technology Network) (Cantlon dan Koenig, 1991). Kemitraan atau joint dapat dilakukan dalam beberapa hal, misalkan joint modal, joint produksi, pemasaran atau pengembangan. Dalam melakukan joint diperlukan persyaratan, antara lain: kebutuhan atau permintaan pasar atas barang yang akan dimitrakan cukup menguntungkan, desain teknis yang inovatif, proposal pembiayaan program yang menarik, analisis sensitivitas indikator finansial, resiko dan usulan pembagian resiko. Lisensi dapat dilakukan oleh inventor pemegang paten kepada pihak lain untuk menjalankan usahanya. Lisensi biasanya dilakukan untuk teknologi canggih (advance technology). Di dalam bisnis makanan salah satu bentuknya adalah franchise. Jual putus dapat dikembangkan melalui paket-paket teknologi. Beberapa perusahaan lebih menyukai sistem ini. Misalkan membeli atau memesan teknologi khusus kepada inventor. Bila inventor diberi pilihan boleh lebih dari satu dalam menjalankan strategi komersialisasi maka prioritas bentuk komersialisasi sesuai harapan inventor mayoritas memilih usaha baru (spin off). Sekitar $40 \%$ memberikan pilihan membutuhkan pihak lain dalam hal ini pengelola invensi (Gambar 4).

Mayoritas inventor mengharapkan invensinya dikembangkan dengan usaha baru (spin off), tetapi inventor memiliki keterbatasan terutama jiwa bisnis yang berani mengambil resiko, fokus, dan tim operasional. Pebisnis yang berminat umumnya lebih tertarik ke joint dimana usahanya sudah berjalan dan memiliki pasar. Padahal strategi joint membutuhkan usaha yang sudah berjalan.

\section{Perkiraan kebutuhan modal}

Kebutuhan modal untuk menuju komersialisasi beragam. Hal ini tergantung cara, alat produksi, bahan baku, operasional tim, biaya pemasaran dan hal-hal lain. Sebagian inventor sudah memiliki studi kelayakan bisnis sehingga relatif mudah dikomunikasikan kebutuhan modal komersialiasi dan sebagian lain berdasarkan perkiraan yang sifatnya intuitif. Bahkan ada yang memberikan perspektif tergantung pasar yang dilayani sehingga memberikan alternatif kebutuhan modal lebih dari satu.

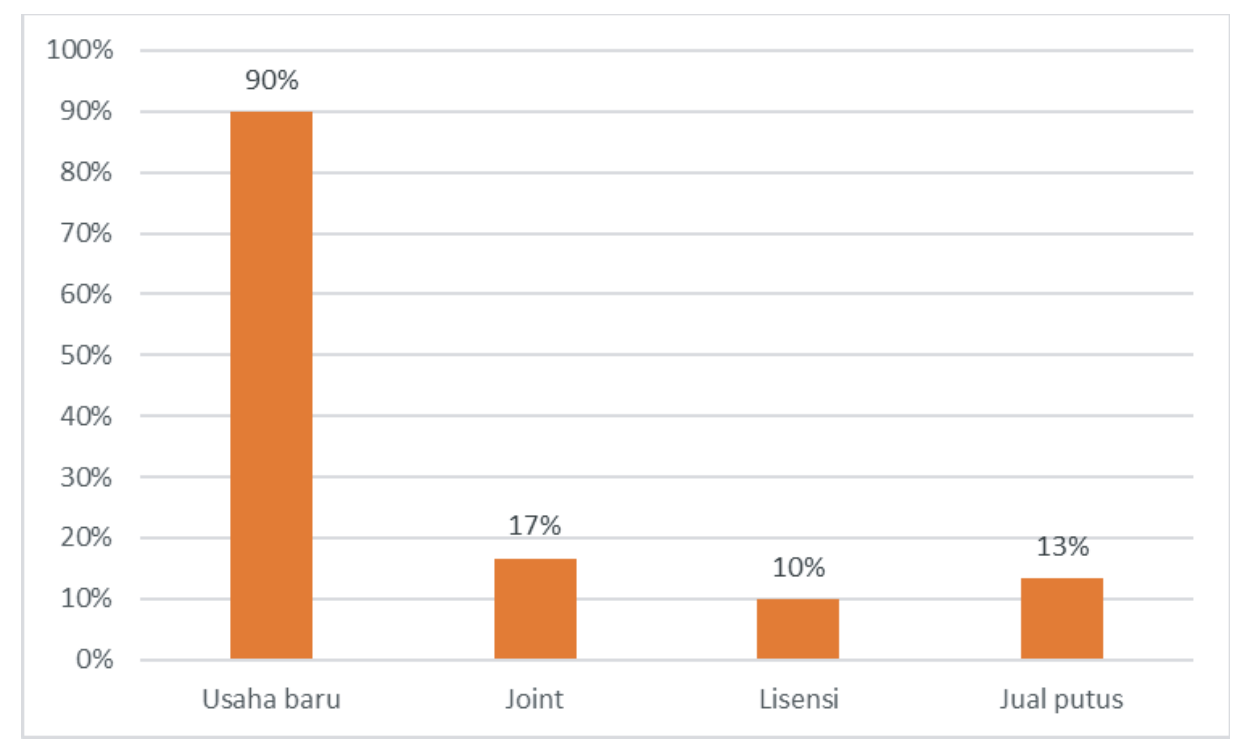

Gambar 4 Preferensi inventor terhadap bentuk komersialisasi (Andrianto, 2011) 


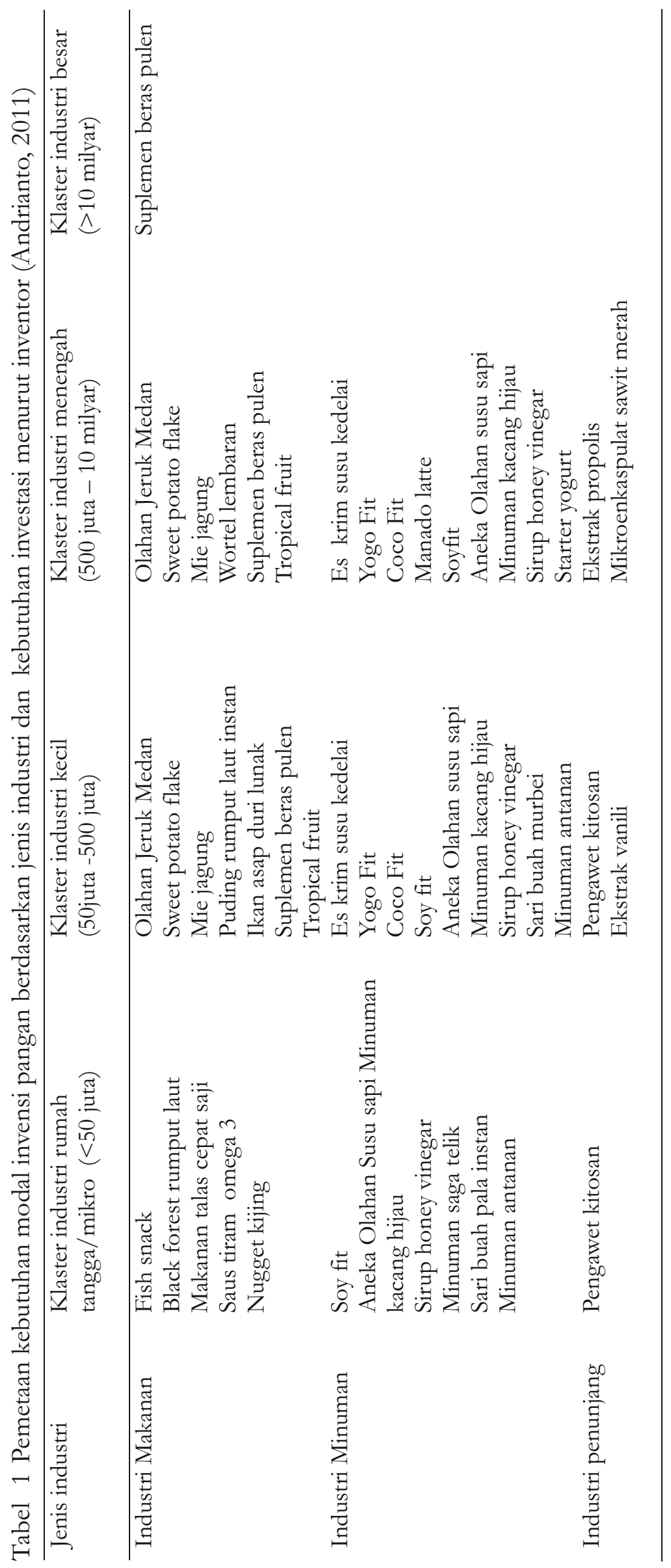




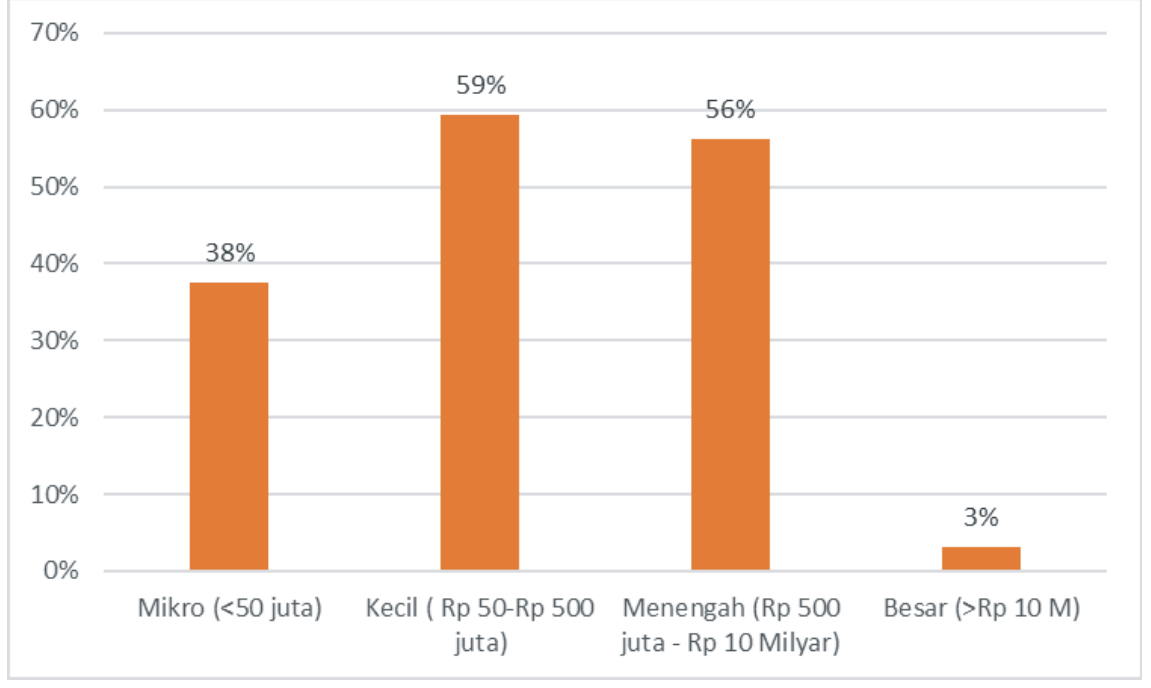

Gambar 5 Perkiraan kebutuhan modal komersialisasi (Andrianto, 2011)

Kebutuhan modal dikelompokkan kedalam mikro, kecil, menengah dan besar. Modal mikro bisa dipenuhi sendiri oleh inventor dan timnya, sedangkan lainnya membutuhkan investor. Bila diberikan pilihan boleh lebih dari satu skenario kebutuhan modal, maka mayoritas memilih kebutuhan modal kecil dan menengah (Gambar 5). Contoh pemetaan kebutuhan modal invensi pangan disajikan dalam Tabel 1.

Keinginan pengembangan komersialisasi melalui spin off cukup beralasan walaupun persentasenya masih kecil tetapi semangat inventor cukup besar dan ketertarikan investor juga masih terbatas. Disis lain hasil kajian Hu dan Mathews (2009) menyimpulkan perusahaan besar cenderung memanfaatkan intangible asset universitas, sedangkan perusahaan menengah dan kecil cenderung memanfaatkan untuk kepentingan pemasaran dibanding memanfaatkan hasil penelitian perguruan tinggi. Crawford dan Benedetto (2008) menyarankan pengembang-an produk baru secara sistemik dengan melibatkan tim multidisiplin. University spin off juga dapat dilakukan melalui sinergi dengan fakultas yang mengembangkan bisnis, melakukan proyek melalui mata kuliah dan penelitian serta pemberdayaan alumni muda.

\section{REFERENSI}

[DRI IPB] Direktorat Riset dan Inovasi Institut Pertanian Bogor. 2014. 278 Inovasi IPB dalam 721 Inovasi Indonesia. IPB. Bogor.

[DRKS IPB] Direktorat Riset dan Kajian Strategis, Institut Pertanian Bogor. 2010. Teknologi IPB untuk Industri Bidang MakananMinuman. Bogor, Dit. RKS IPB. Bogor.

[DRKS IPB] Direktorat Riset dan Kajian Strategis, Institut Pertanian Bogor. 2011. Buku-buku Terkait HKI. www.rks.ipb.ac.id. Diakses pada 20 Februari 2011.

[Ditjen Haki RI] Direktorat Jendral Hak atas Kekayaan Intelektual Republik Indoensia 2005. Hak Kekayaan Intelektual : Buku Panduan. Direktorat Jenderal Hak Kekayaan Intelektual. Departemen Hukum dan Hak Asasi Manusia Republik Indonesia. Jakarta. 
[KNRT] Kementerian Negara Riset dan Teknologi. 2006. Peraturan Pemerintah Republik Indonesia Nomor 20 Tahun 2005 tentang Alih Teknologi Kekayaan Intelektual serta Hasil Penelitian dan Pengembangan oleh Perguruan Tinggi dan Lembaga Penelitian dan Pengembangan Kementerian Negara Riset dan Teknologi RI, Jakarta.

Allen, D.N., Norling, F. 1991. Exploring Perceived Threats in Faculty Commerzialition of Research. (book chapter, p:85-102). University Spin-off Companies : Economic Development, Faculty Entrepreneurs, and Technology Transfer. Rowman \& Litlefield Publishers, Inc. 307pp. Maryland.

Andrianto, M.S., Munandar, J.M., Irwanto, A.K. 2011. Strategic Analysis of the Invention Commercialization to Increase Competitiveness (Case Study on Food Beverage Invension of IPB). Proceedings of The 1st International Conference on Information Systems For Business Competitiveness (ICISBC) 2011. UNDIP. Semarang.

Andrianto, M.S. 2011. Analisis Strategi Komersialisasi Invensi Makanan-Minuman IPB. Tesis. SPS IPB. Bogor.

Banjade, M.R., Paudel, N.S., Ojha, H., Mc Dougall, C., Prabhu, R. 2007. Conceptualising meso-level governance in the management of commons: lessons from Nepal's community forestry. Journal of Forest and Livelihood, 6(1), 48-58.

Brett, A.M., Gibson, D.V., Smilor, R.W. 1991. University Spin-off Companies : Economic Development, Faculty Entrepreneurs, and Technology Transfer. Rowman \& Litlefield
Publishers, Inc. 307pp Maryland.

Cantlon, J.E., Koenig, H.E. 1991. Global Economic Competitiveness and the Landgrant University. (book chapter p:3-29). University Spin-off Companies : Economic Development, Faculty Entrepreneurs, and Technology Transfer Rowman \& Litlefield Publishers, Inc. 307pp Maryland.

Crawford, M., Benedetto, A. 2008. New Product Management. McGraw-Hill Educatin. Singapore.

Dharmawan, B. 2007. Pemodelan dan Rancang Bangun System Valuasi Teknologi Berorientasi Paten di Lingkungan Institut Pertanian Bogor (IPB). Tesis SPS TIP IPB. Bogor.

Febriani, E. 2014. Pengembangan Model Pengukuran Kinerja untuk Pengembangan Inovasi dan Komersialisasi Produk Agroindustri Berbasis Digital Business Ecosystem. Tesis. SPS IPB. Bogor.

Gibson, D.V., Smilor, R.W. 1991. The Role of Research Univesity in Creating and Sustaining the U.S.Technopolis. (book chapter, p:31-70). University Spin-off Companies : Economic Development, Faculty Entrepreneurs, and Technology Transfer. Rowman \& Litlefield Publishers, Inc.307pp. Maryland.

Hu, Mei-Chih., Mathews, J.A. 2009. Estimating the Innovation Effects of UniversityIndustry-Government Linkages : The Case of Taiwan. J. of Management \& Organization, (15/2). 2009:pp. 138-154.

Jeurissen, R. 1997. Integrating micro, meso and macro levels in business ethics. Ethical Perspectives, 2, 246-254. https://doi.org/10.2143/EP.4.4.562986.

Khalil, T.M. 2000. Management of Technology : 
The Key to Competitiveness and Wealth Creation. Mc-Graw Hill. Boston.

Nugrahani, N. 2011. Analisis Strategi Pengembangan Komersialisasi Jagung Hibrida Hasil Invensi melalui Kerjasama Lisensi. Tesis. SPS IPB. Bogor.

Rizki, D.A., Munandar, J.M., Andrianto, M.S., 2013. Analisis Persepsi Konsumen dan Strategi Pemasaran Beras Analog (Analog rice). Jurnal Manajemen dan Organisasi Vol IV(2), p144-162.

Shanahan, E.A., MCBeth, M.K., Hathawat, P.L. 2011. Narrative Policy Framework: The Influence of Media Policy Narratives on Public Opinion. Politics \& Policy, 39: 373-400. doi:10.1111/j.17471346.2011.00295.x. 